\title{
El Navfrágio da nao S. Alberto, e itinerário da gente que delle se salvov, de João Baptista Lavanha: los paratextos de 1597 y los de 1736
}

\author{
Alma Delia Miranda Aguilar \\ Universidad Nacional Autónoma de México
}

La redacción de paratextos como títulos, portadas y dedicatorias entre los siglos XVI y XVIII tenía implicaciones políticas de peso. Éstos mostraban la dependencia de los autores en relación con personajes poderosos, como monarcas y miembros de la nobleza. Durante este periodo, modificar los paratextos implicaba la transformación de los objetivos del autor. En este artículo se comparan e interpretan los paratextos de la edición de 1597 del Navfrágio da nao S. Alberto, e itinerario da gente que delle se salvov, del cosmógrafo mayor João Baptista Lavanha, y los de la edición de 1736, incluida en la antología História trágicomaritima, de Bernardo Gomes de Brito. Mientras Lavanha dedicó su relación al futuro Felipe III, Brito dedicó su compilación al rey D. João V, miembro de la dinastía que restauró la monarquía en Portugal.

PALABRAS ClaVE: paratextos, História trágico-marítima, João Baptista Lavanha, Bernardo Gomes de Brito, edición.

Composing paratexts such as titles, book covers and dedications between the $16^{\text {th }}$ and $18^{\text {th }}$ centuries had important political implications. This action shows the author's strong reliance on powerful figures, who could be the kings, other members of royal family and nobility. During this period, the modification of paratexts implied the transformation of the objectives of the author. In this article, I compare the paratexts of the 1597 edition of Navfrágio da nao S. Alberto, e itinerario da gente que delle se salvov, by the Portuguese royal cosmographer João Baptista Lavanha, and those of 1736, included in Bernardo Gomes de Brito's compilation named História trágico-maritima. Lavanha dedicated his work to the future Philip III, whereas Bernardo Gomes de Brito dedicated his anthology to king João $\mathrm{V}$, a member of the dynasty who restored the Portuguese monarchy.

KeY WORDS: paratexts, História trágico-maritima, João Baptista Lavanha, Bernardo Gomes de Brito, editing.

En 1597 la imprenta lisboeta de Alexandre Siqueira sacó a la luz el Navfrágio da nao S. Alberto, e itinerario da gente que delle se salvov, de João Baptista Lavanha, cosmógrafo mayor de Felipe II de España y I de Portugal. En su camino de Cochín a Lisboa, la embarcación había naufragado en las costas de lo que hoy es Mozambique en el año 
de 1593. Iban más de trescientas personas a bordo, más de la mitad eran esclavos. Lavanha había nacido en Lisboa en 1555 en el seno de una familia judía conversa y se presume que el rey Don Sebastián lo había enviado a Roma para que allí estudiara matemáticas, lo cual habría ocurrido entre 1572 y 1578 (O'Connor y Robertson: 2014). Pero justamente para 1578, el reino que lo habría patrocinado ya era otro muy distinto: Don Sebastião había muerto y Portugal se encontraba en medio de una crisis de sucesión que se resolvió en 1580 a favor del rey español Felipe II. La transformación política que implicó la Unión Ibérica se manifestó en los paratextos de la relación de Lavanha, que son el centro del análisis de este trabajo. La portada, las licencias y la dedicatoria revelan que ser un vasallo portugués de reyes españoles implicaba un aparato discursivo conforme a la situación, mismo que resultó problemático una vez que Portugal volvió a ser un reino independiente. La comparación de los paratextos de la primera edición de 1597 con los que aparecen en la versión editada de 1736 revelan de qué modo la política pudo intervenir en la composición de los paratextos y, por ende, en su comprensión e interpretación.

\section{El contexto político de João Baptista Lavanha}

La sucesión había sido compleja, por decir lo menos: el rey Sebastião había muerto en Alcazarquivir en 1578 sin dejar descendencia; la corona le correspondía entonces al varón más cercano al linaje del monarca, pero el rey no tenía hermanos, ${ }^{1}$ así que la corona recayó en su tío, que tenía la desventaja de ser cardenal. Pese a ello, don Henrique asumió la corona de manera temporal, retrasando la crisis hasta 1580 , cuando murió. De los pretendientes a la corona, sólo dos eran legítimos: el rey Felipe II de España y la duquesa Catarina de Braganza, quien, por ser mujer y representar la independencia, estaba en una posición debilitada. Ambos eran nietos del rey Manuel I. La nobleza se inclinaba por una unión ibérica, porque la adhesión significaba que los nobles podrían mantener su estado: "cargos, fortunas e ofícios cortesãos" (Saraiva, 1988: 170). Los grandes burgueses también apoyaron esta opción, que les abría mayores oportunidades comerciales. Sin embargo, el apoyo popular lo consiguió don António, prior do Crato, nieto también, pero ilegítimo, de don Manuel I. Menestrales, agricultores, pescadores y demás integrantes del segmento popular constituyeron el débil apoyo bélico de don António, quien no pudo vencer al ejército de Felipe II, que protegió a la nobleza y venció a los partidarios de don António en Lisboa.

En las cortes de 1581 en Tomar, donde el rey español fue proclamado Felipe I de Portugal, el monarca anunció los estatutos especiales que debían regir a los nobles

\footnotetext{
${ }^{1}$ De manera no tan sorprendente, pues las causas eran muy probablemente endogámicas, el rey João III, su padre, había visto morir a nueve hijos; lo paradójico es que no vio nacer a don Sebastião, pues murió sólo unos días antes de que éste naciera.
} 
portugueses y que les proveían de innegables beneficios. Entre ellos, estaba la posibilidad de que pudieran ser nombrados para ejercer funciones públicas en España (Saraiva: 200), lo cual implicó el desplazamiento de la nobleza poderosa a Madrid.

La adhesión de Portugal hizo del conocimiento de Felipe II el atraso de España en lo que concernía a la navegación. En este contexto, los conocimientos de Lavanha al respecto le granjearon la acogida de Felipe II en la corte y un ascenso en responsabilidades y poderes. No sólo llegó a ser cosmógrafo mayor, sino también cronista real. Lavanha trabajó entre Portugal y España como ingeniero, matemático, cartógrafo, cronista y cosmógrafo. Su sólida posición en el seno de la corte filipina se puede constatar con el siguiente testimonio que informa de sus constantes retrasos en la entrega de unos mapas de Aragón:

Todo esto que he dicho a V. S. ha pasado en presencia del dicho Sr. Dr. Ardit, el cual creo que hará la misma relación a V. S. y no puedo dar más esperanzas de las que se me dan a mí que harto quisiera no estar colgado dellas sino cumplir con mi obligación de servir a V. S. y darle gusto en todo, pero no está en mi mano lo que pende de la ajena y ser este portugués tan poderoso y querido de su Majestad, que aunque quisiera llevar este negocio por términos de Justicia, fuera imposible hacerle cumplir, porque es primero servir al Rey, como me ha dicho muchas veces (Lavanha, 1895: 1xii). ${ }^{2}$

En síntesis, para Lavanha las crisis dinástica y la sucesión fueron hechos que terminaron por beneficiarlo. Y la publicación de la primera edición del naufragio que me ocupa es una muestra de ello y de su habilidad para moverse en la corte.

La fecha de las licencias del impreso informa que la relación del naufragio estaba lista en 1596. Antes de escribir su texto, Lavanha había revisado los cartapacios del piloto y había verificado la información con Nuno Velho Pereira, capitán mayor, pues el cosmógrafo no es un narrador testimonial. Es probable que el impacto del texto de Lavanha en el siglo XVII haya sido escaso, pues no hay noticia de una segunda edición, pero en 1736 Bernardo Gomes de Brito incluyó esta relación en el segundo tomo la História trágico-marítima, compilación que ofreció para celebrar la apertura de la Academia de la Historia. De este modo, el texto de Lavanha ingresó a la consagración, porque, tras publicarse en la antología de Brito, hubo una serie de copias piratas que pretendían pasar como impresos del siglo XVII (Boxer, 1957: 24). ${ }^{3}$ Estos falsos impresos del XVII hablan más del impacto de la antología de Brito que del éxito de la relación suelta de Lavanha a finales del siglo XVI. Por eso conviene hacer una breve parada en la compilación del XVIII.

\footnotetext{
${ }^{2}$ Para 1619, fecha del testimonio, Lavanha tenía un retraso de cinco años en la entrega de su trabajo. He modernizado la ortografía en la cita.

${ }^{3}$ Como antología, la História trágico-marítima no tiene reediciones sólo en el siglo xx (Moniz: 45-46).
} 


\section{La História trágico-marítima y sus problemas}

Aunque según rezan las licencias éste estaba listo desde 1729, es hasta 1735 cuando sale a la luz el primer tomo de la História trágico-marítima, antología de relaciones de viajes de ultramar — casi todos desastrados por causa de naufragios—, todos ellos de la segunda mitad del siglo XVI. En esta primera entrega Bernardo Gomes de Brito recopiló seis relaciones. El compilador le dedicó "estos fragmentos históricos" al rey D. João $V$ y en 1736 apareció el segundo y último volumen, también con seis relaciones. A partir de ese momento, la historiografía y la crítica literarias que abordan estos textos, en lugar de referirse de manera consistente y genérica a relaciones de viajes desastrados, relaciones de viaje o relaciones de naufragios, hablan casi siempre de la História trágico-marítima ${ }^{4}$ lo cual conlleva algunos problemas.

En primer lugar, se cae en el peligro de interpretar las relaciones a la luz de la palabra historia y del adjetivo trágico que usó el compilador en el título. En este sentido, se entiende que Boxer, un historiador, haya sido el primero en dedicarle estudios sistemáticos a estas relaciones, que tienen una innegable matriz literaria en su composición, tomando en cuenta que en esa época se escribía a partir del conocimiento de la retórica y que los autores usaban los recursos de acuerdo con la finalidad de lo escrito. Desde luego que el tomo I registra una innegable cohesión temática y los autores buscaban imitar y/o superar la relación pionera y más célebre: la del naufragio de Don Manuel de Sousa Sepúlveda, que es la primera del tomo. Su historia ejemplifica como pocas el tópico de cambio de fortuna, es un portentoso antihéroe y el autor supo transmitir sus penalidades apoyado en una retórica efectiva que buscaba sobre todo conmover al receptor, por lo cual esta relación fue la que se reeditó más, incluso hubo copias pirata de ella (Boxer, 1957: 9). La triste fama de su protagonista mereció obras cronísticas y literarias, menciones e interpretaciones a propósito de este suceso. ${ }^{5}$ Sin embargo, ya el tomo II tiene relaciones que se desvían de esa cohesión. ¿Quién podría sostener que la relación del jesuita Gaspar Afonso tiene como finalidad conmover al lector a partir de desventuras y penalidades, cuando lo que prevalece en su texto es la fascinación por la naturaleza americana y su reprobación de los abusos de los colonizadores? ${ }^{6}$

${ }^{4}$ La estudiosa italiana Giulia Lanciani es una excepción, lo cual se puede comprobar al revisar los títulos de sus estudios o ediciones: Os relatos de naufrágios na literatura portuguesa dos séculos XVI e XVII, Naufragi e peregrinazioni americane di Gaspar Afonso y Tempesta e naufragi sulle vie delle Indie.

${ }^{5}$ En la crónica, la Década VI de Diogo de Couto sigue el contenido de la relación, pero añade información de la vida del personaje en Asia, antes del viaje de regreso a Portugal, cuando naufraga, pierde a su familia en la dura peregrinación por tierra, pierde la razón y termina por internarse en las sabanas africanas sin que nunca vuelva a saberse de él. En la literatura, Camões le dedica un par de octavas en el canto V de Os Lusíadas (1572); además hay un pasaje en la Elegíada de Luís Pereira Brandão (1588); Jerónimo Corte Real escribe el largo poema Sepúlveda \& Dona Lianor (1594); Francisco de Contreras la Nave trágica de la India de Portugal (1624) y Tirso de Molina Escarmientos para el cuerdo.

${ }^{6}$ En su relación hay un solo episodio en que la embarcación está en grave peligro. Es verdad también que el autor y sus compañeros recorren desde Salvador de Bahía hasta Cuba porque la nao sufre avería tras 
Es muy elocuente en su prólogo cuando menciona la reacción de quien lo oía contar este viaje; en este sentido, su receptor tiene una emoción muy distinta a la que despiertan las desventuras de Manuel de Sousa Sepúlveda: "O desejo e sede com que isto me pediu quem por muitas vías me podía mandar [...] e o gosto com que me ouvia e fazia referir algumas cousas que por nós passaram ou nos por elas estes anos que andámos errando tantos mares e terras, quantas nunca Ulisses imaginou que podía haver para se navegar e errar, me obrigou a lho pôr por escrito" (Brito, 1957: III: 81, subrayado mío). Tal como sucede con el jesuita Gaspar Afonso que acabo de citar, la intención de João Baptista Lavanha tampoco es conmover a su receptor.

En segundo lugar, hay un fuerte problema de fiabilidad textual, pues Gomes de Brito alteró todas las relaciones que incluyó, como lo señaló desde 1957 Boxer:

[...] the História trágico-maritima is nowadays universally recognized as one of the masterpieces of Portuguese prose, but is often praised for the wrong reasons. No discrimination is made by the critics (with the notable exception of M. Rodrigues Lapa) between the language and style of the original narratives, and those of the various versions published by Gomes de Brito. [...] Gomes de Brito sometimes took considerable liberties with his sources [...]. On the whole it must, I think, be admitted that he did this part of his work pretty well, as the História trágico-maritima reads very smoothly. But it is obviously desirable that the texts of the first editions should be reprinted as their writers wrote them, so that we can see exactly what liberties Gomes de Brito took with his originals (47).

A pesar de que han transcurrido más de cincuenta años, el señalamiento de Boxer continúa vigente, pues son pocos quienes han estudiado los textos originales y todavía no hay una sola edición crítica de la antología de Brito que señale cuáles fueron las partes y pasajes editados tanto en relación con las primeras ediciones como con las fuentes de Brito, pues no en todos los casos coinciden. Además, prácticamente todas las ediciones modernas de esa antología tienen no pocos errores, erratas y descuidos. Los textos más "limpios" y con mejores notas son los de la bonita edición ilustrada de António Sérgio ${ }^{7}$ - ya de colección-, quien, no obstante, emitió en algunas de las introducciones que preceden a cada texto juicios de valor que pueden influir de manera negativa en la comprensión de los mismos. ${ }^{8}$ Sólo a partir de la segunda mitad del

avería, pero su narración no se concentra en referir los problemas de la nao, sino todo lo que observa cada vez que desciende de la embarcación.

${ }^{7}$ El tomo I apareció en 1956; de 1957 son los tomos II y III.

${ }^{8}$ Ilustro con dos ejemplos que considero exagerados y con los cuales me es imposible concordar. En la introducción de la Relaçaõ da viagem e naufragio da nao S. Paulo afirma sobre el autor: "era um boticário impregnado de eruditismo greco-latino da época, infelizmente um tanto retórico e ansioso de alardear os seus conhecimentos literários". Y sobre el texto afirma que "é dos mais imperfeitos, frequentemente obscuro (Brito, 1957: II: 12). Acerca del padre jesuita Gaspar Afonso en la Relaçaõ da viagem e successo que teve a Nao S. Francisco, su juicio no es menos hostil: "homem retórico, escreve com pretensiosismo, amplificação, pedantice, alardeando a sua sabença em letras clássicas, sobretudo nas obras do poeta Ovídio, num estilo que contrasta com a simplicidade elegante (tão de molde à expressão de um pensar de cientista) que 
siglo XX se comenzaron a realizar estudios que han tenido como base la fuente original o las primeras ediciones, sobre todo los de Giulia Lanciani, quien editó y publicó ocho narraciones y además informa de una veintena de textos repartidos entre los fondos de la Biblioteca Nacional de Lisboa, el Palacio de Ajuda, el Arquivo Nacional da Torre do Tombo, bibliotecas extranjeras y fondos privados. Sin embargo, en el ámbito académico ha resultado prácticamente imposible establecer distancia con el título de la antología que Brito nos heredó. Véanse, entre otros, el volumen colectivo $A$ História trágico-marítima: análises e perspectivas (Seixo y Carvalho, 1996) y $A$ História trágico-marítima: identidade e condição humana, versión en libro de la tesis doctoral de António Manuel de Andrade Moniz (2001).

\section{Los paratextos de 1597 y de 1736}

Son numerosos los ejemplos de intelectuales portugueses que en el siglo XVIII rechazan los vínculos que la cultura portuguesa había tenido y aún mantenía con España desde la Edad Media. Para esos intelectuales, los años entre 1580 y 1640, el periodo que corresponde al Siglo de Oro español y durante el cual los Felipes castellanos fueron monarcas de Portugal, son especialmente dignos de rechazo. Luís António Verney, por ejemplo, da vehementes tundas verbales a todos aquellos poetas que aún en el XVIII imitan a autores como Góngora o Gracián y enfatiza que ese estilo es de mal gusto. ${ }^{9}$ Lo mismo ocurre con poetas como Pedro António Correia Garção (1778) en sus Orações. ${ }^{10}$ En el Portugal dieciochesco se respiraban aires de un nacionalismo que se construía en gran medida a partir del rechazo de lo español. Esto explica la edición de los paratextos de la relación del naufragio que narra Lavanha, pues la motivación de Brito es ideológica, del mismo modo que era política y cortesana la de Lavanha en la edición de 1597.

Boxer afirmaba en 1957 que lo ideal sería conocer los textos originales para leer exactamente lo que los autores querían decir. La ecdótica nos ha enseñado la importancia del estudio de fuentes originales y Genette puso el acento en el hecho de que los paratextos tienen funciones en nombre de intereses o efectos $(1987: 8,16)$. Por ello, el cotejo de los dos textos debe empezar desde los títulos. Brito modifica el título original en el índex del tomo II de la antología. El texto de Lavanha se presenta como:

caracteriza o relato imediatamente anterior" (Brito, 1957: II: 80). El relato al que alude Sérgio es el de João Baptista Lavanha.

9 "Deste princípio nasceram aquelas ridículas composições que tanto reinaram no século da ignorância (digo no fim do século XVI de Cristo e metade do século XVII) e, desterradas dos países mais cultos, ainda hoje se conservam em Portugal e nas mais Espanhas" (Verney, 1950: 210).

10 "Devíamos dar ouvidos a quem desejava a nossa ruína, porque não podia ouvir a nossa fama; a quem queria que nos calássemos, porque não pode falar como nós falamos; a quem desaprova os nossos versos, porque não tinham consoantes, ou porque imitávamos Horácio, Píndaro, Teócrito e Bion? A quem estranhava a nossa dicção, porque adoptávamos a de Camões, de Bernardes, e de Ferreira; a quem desaprovava a nobre simplicidade de nossos pensamentos, porque é escravo de Góngora?” (377). 
"NAUFRAGIO da Nao Santo Alberto no Penedo das Fontes no anno de 1593". Éste es una versión corta de la portada interior. Los cambios entre los datos de la portada original de 1597 (izquierda) y los de la portadilla de 1736 (derecha) son evidentes:

\section{NAVFRAGIO DA NAO S \\ ALBERTO, E ITINERÁRIO DA \\ GENTE, QVE DELLE SE \\ SALVOV}

De Ioão Baptista Lavanha

Cosmopgrapho mòr

de Sua Magestade.

DEDICADO AO PRÍNCIPE

DOM PHILIPPE NOSSO

SENHOR EM LISBOA

Em casa de Alexandre Siqueira.

Anno MDXCVII

Com Licença, \& Privilegio

\author{
RELAÇAÕ DO \\ NAUFRAGIO DA NAO \\ S. ALBERTO
}

No Penedo das Fontes no anno de 1593.

E itinerario da gente, que delle se salvou, athè chegarem a Moçambique.

[Grabado de un naufragio]

\section{ESCRITA}

Por JOAÕ BAPTISTA LAVANHA

Cosmografo mòr de Sua Magestade

No anno de 1597.

\section{HISTORIA}

TRAGICO-MAR ITIMA

Em que fe eforevem cbronologicamente os Nain fragios que tiveráo as Naos de Portugal, depois que fe poz em exercicio a $N a-$ vegaçaó da India.

TOMO SEGUNDO $O F F E R E C I D O$

A Augufta Mageftade do muito Alto, e muito

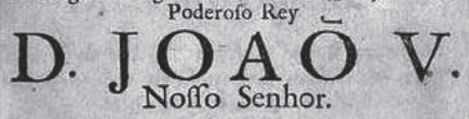

POR BERNARDO GOMES DE BRITO.

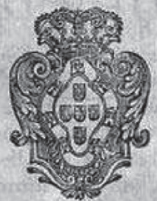

LISBOA OCCIDENTAL,

$\mathrm{Na}$ Officina da Congregaçaó do Oratorio. M. DCC. XXXVI. Com todas as ilonf pas nocoffarias.

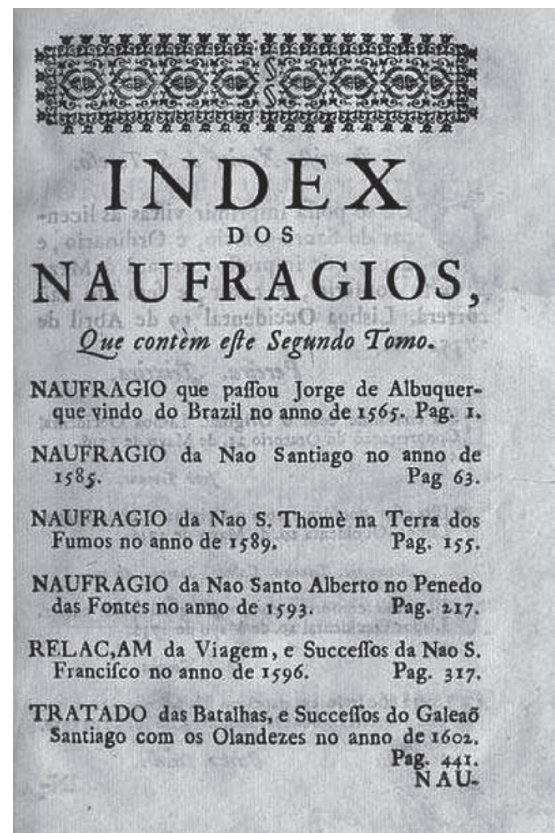


Para la portadilla, Brito suprimió la noticia de la licencia y el privilegio que el rey Felipe II le otorgó a Lavanha por diez años, pero lo más importante es que no incluyó la dedicatoria del autor al futuro Felipe III.

Cuando habla del papel de la dedicatoria y de la portada en la época del nacimiento de la imprenta, Jean François Maillard señala su riqueza formal y funcional, y apunta que, "On se trouve ainsi en présence non d'une dédicace, mais d'un ensemble de pièces liminaires à considérer globalement comme l'apparat dédicatoire de l'œuvre" (2003: 26). En los dos siglos posteriores no cambió demasiado la función de tal aparato dedicatorio. En el contexto de Lavanha, es un ejercicio vivo que expone públicamente el homenaje del autor al dedicatario y que manifiesta la relación entre ambos. De tal modo que dedicar una obra se convierte en un acto público de fidelidad y de servicio. Funciona, además, como una suerte de petición, dado que los autores esperan algún tipo de gracia, beneficio o protección por parte del dedicatario, porque se trata de personajes jerárquicamente superiores al autor: detentan poderes. En este sentido, significa también una ostentación pública del círculo en el que se mueve el autor tomando en cuenta que, como afirma Genette, el dedicatario sabe que la obra le será dedicada antes de que se imprima (1987: 113).

Como acto público, la práctica de la dedicatoria comenzaba con la inclusión del nombre y rango del dedicatario en la portada. La de 1597 es más bien escueta y su brevedad obedece a que se indica que el autor tiene un cargo designado por el rey ("cosmographo mòr de Sua Magestade) y dedica la obra al príncipe heredero, es decir, por encima del futuro Felipe III sólo está el rey. No obstante, de manera sorprendente, en la portada destacan más la palabra Navfragio y el nombre y cargo de Lavanha que el del príncipe Felipe, referido como "Su Majestad". De hecho, los datos del cosmógrafo son los que tienen los tipos más grandes en la portada entera. ¿Soberbia del autor? ¿Animadversión del tipógrafo? ¿Precaución para no encender los ánimos de los nacionalistas? En todo caso no es posible atribuir ingenuidad a la conformación tipográfica de la portada del impreso si tomamos en cuenta que otros estudios de los paratextos de la época arrojan como resultado que prácticamente nada es producto del azar, como lo explica Mònica Güell para el caso de las portadas de libros de poesía castellana del mismo periodo (2009).

Otro asunto a señalar es la ausencia de elementos iconográficos en la portada de 1597 y su inclusión en la portadilla de 1736. ¿Cómo es posible que el impreso de una obra de un personaje así de poderoso fuera tan sobrio? La mayor parte de las primeras ediciones de las relaciones de naufragio en Portugal durante el siglo XVI tenían un grabado de un barco a punto de hundirse y gente que clamaba por socorro (Boxer, 1957: 7-29), lo cual inducía a la conmoción desde antes de que comenzara propiamente el relato. Por ello, ha de entenderse que fue un acto deliberado presentar la portada sin imágenes. No obstante, los tipos grandes de la palabra navfragio pretendían llamar la atención y dan noticia de la fama de relaciones que contaban estas penalidades. La relación de Lavanha lanza el anzuelo para despertar la curiosidad del lector, pero sin sorprenderlo ni conmoverlo con un recurso iconográfico. Esto funciona de modo distinto con la portadilla de 1736, en la cual la imagen promete un pathos que la narración de Lavanha no cumple. 
La "Dedicatoria" va más allá de palabras elogiosas en homenaje al futuro rey y tiene una función prefacial, tal cual numerosas dedicatorias (Genette, 1987: 107; Voinier, 2009: 291), por eso conviene analizarlo por partes. El inicio contradice el adjetivo trágico de la antología de Brito, pues Lavanha anuncia: "Descobriram os portugueses que se salvaram do naufrágio da nao S. Alberto no ano de XCIII um grande espaço da bárbara Cafraria \& por ela romperam e abriram nova estrada, pela qual, caminhando com comodidades não esperadas, chegaram à Baia de Espírito Santo" (1597). ${ }^{11}$ En otras palabras, en primera instancia no hay una dimensión dramática ni trágica en lo que se va a contar en la relación y esto se debe, en gran medida, según Lavanha, a la pericia del capitán mayor, Nuno Velho Pereira. Esto previene de la falta en ella del deseo de conmover mediante el infortunio. No se puede afirmar que esto se debe a que Lavanha no fue testigo directo, pues el autor de la relación del naufragio de Manuel de Sousa Sepúlveda tampoco estuvo en ese naufragio y escribe lo que le contó un superviviente. ${ }^{12}$ Por lo tanto, el estilo es una decisión autoral de Lavanha y se explica en el hecho de que el texto es también un manual para náufragos en el que debe estar presente el ejemplo del ánimo y la astucia por la sobrevivencia, por la salvación. Cuando Brito cortó y editó el original terminó por deturpar la recepción del texto, porque "e Itinerário da gente que delle se salvov" remite al carácter didáctico y práctico de la relación. Es un itinerario porque hay un riguroso orden cronológico en la narración y, sobre todo, porque tiene la función de señalar un camino, lo que se explica en el hecho de que Lavanha había tenido frente a sus ojos el cartapacio del piloto de la nao.

La parte medular de la dedicatoria en el sentido de homenaje es donde el autor hace explícita la intención de su texto, donde confirma lo anterior (mis subrayados):

E como a relação deste camino seja de muita importância, para aviso dos que naquela costa se perderem (o que Deus não permita que suceda) encarregaram-me os Governadores deste Reino que a fizesse. É esta que neste volumen vai às maõs de V. A. em penhor de outro maior que vou acabando da descrição \& história de todos os estados da Monarquia de S. Majestade (nos quais sucederá V. A. depois de largos anos de sua vida) \& das genealogias dos reis y príncipes deles. Obra que receberá o preço da grandeza do sujeito \& muito mais de ser a V. A. dedicada, donde a esta também se lhe comunica.

Por una parte, hay una deliberada intención de que la relación tenga un fin utilitario y sea una referencia para futuros náufragos, por eso la intención medular del texto es didáctica, de ahí que esto le impida ser trágica. Por otra parte, y sin duda esto motivó

${ }^{11}$ Los folios de los paratextos no están numerados. La numeración empieza cuando inicia propiamente la narración. Los subrayados son míos.

${ }^{12}[\ldots]$ um tal Álvaro Fernandes [...] me contou isto muito particularmente, que por acerto achei aqui em Moçambique no ano de mil quinhentos e cinquenta e quatro. E por me parecer história que daría aviso e bom exemplo a todos, escrevi os trabalhos e morte deste Fidalgo e de toda a sua companhia, para que os homens que andam pelo mar se encomendem continuamente a Deus e a Nossa Senhora, que rogue por todos. Amen" (Brito, 1956: I: 13). 
la supresión de la dedicatoria en la antología, no se trataba de un ejercicio monótono de captatio benevolentiae. El autor no estaba recurriendo a una fórmula tópica o vacía, sino que estaba tratando de granjearse la voluntad del príncipe heredero. Es obsequioso el carácter de la dedicatoria, como no podría ser de otra manera tomando en cuenta quién es el destinatario, por eso remata su ejercicio de vasallaje con el anuncio de una obra mayor también dedicada al príncipe. El portugués estaba consciente de que Felipe II estaba llegando a sus últimos días, era un rey viejo, así que necesitaba asegurar que por lo menos se mantuviera su situación en la corte cuando el príncipe ascendiera al trono. Felipe II murió al año siguiente y no cabe duda de que los esfuerzos por ganar los favores de Felipe III le rindieron frutos al cosmógrafo, si tomamos en cuenta el testimonio de la primera cita de este trabajo. Como si esto fuera poco, esta información legitima su autoridad como autor de la obra, pues no sólo es el cosmógrafo mayor sino que además especifica que escribe porque le encargaron la escritura de la obra justamente a él.

Tanto la inclusión de la dedicatoria de Lavanha en la edición de 1597 como la supresión de la misma en el tomo de 1736 expresan aspectos importantes del contexto cultural del autor y del compilador. Para Bernardo Gomes de Brito, Lavanha era un portugués postrándose ante nobles españoles, por eso edita y reescribe el título y prescinde de la dedicatoria. Esto confirma que la omisión y distorsión de los paratextos tienen connotaciones ideológicas. Según el título que le confirió Brito a su trabajo, su antología es trágica, pero también es histórica. Sin embargo, hoy día es innegable que el proceder de Brito ubica la historicidad de la antología en una posición sui géneris y el contraste con la fuente original permite reinterpretar su trabajo. Mientras que en el siglo XVI la dedicatoria representaba una utilidad —e incluso una necesidad — para Lavanha, en el XVIII es digna de omisión para el antologador. A partir de la inclusión y de la supresión del paratexto es posible reconstruir no sólo la personalidad de Lavanha y de Brito, sino también las consecuencias culturales de los cambios políticos. Asimismo es posible entender la compleja situación de cortesanos e intelectuales de origen portugués que vivieron en esa etapa delicada de 1580-1640, porque todos ellos por fuerza tenían que conducirse con habilidad entre aguas portuguesas y tierras españolas. En la práctica, se debían a su rey, cuya corte estaba en Madrid, pero también a su reino de origen: Portugal.

El ejercicio manifiesto de captatio benevolentiae por parte de Lavanha se cruzaba con las propias intenciones de Brito (1735), cuya dedicatoria al rey Don João V no dista del carácter reverencial del cosmógrafo:

Como V. Majestade, por sua Real Grandeza, se fez Augusto Protetor da História, erigindo a sua preclara Academia, parece que permitiu aos afortunados historiadores deste século a glória de recorrer ao seu Real asilo, indulto de que agora me valho para pôr aos Reais Pés de V. Majestade nestes tomos, estes fragmentos históricos, que já perdem o horror de lastimosos na fortuna de dedicados, conseguindo eu para aqueles vassalos desta Coroa (que agora o são de V. Majestade com melhor estrela) nos seus naufrágios o mais feliz porto, senão para as suas vidas, para as suas memórias. O Céu dilate a vida de V. Majestade para felicidade desta Monarquia. 
Cuando Brito expresa "aqueles vassalos desta Coroa, que agora o são de V. Majestade com melhor estrela", enfatiza su nacionalismo al expresar su beneplácito de que esos textos se publiquen en un momento en que el rey es nuevamente un portugués. Podría aducirse también que Brito no publicó la dedicatoria de Lavanha simplemente porque tampoco publicó ningún paratexto de ninguna otra relación, sino simplemente las narraciones; pero estamos comprobando lo que se escapa cuando sólo se toma en cuenta las relaciones como aparecen en la História trágico-marítima y lo que se gana al comparar el texto de la compilación con la edición original.

Tanto el cosmógrafo como el antologador redactan sus dedicatorias con la consciencia de la importancia de ésta porque esperan un beneficio de su trabajo por parte de los monarcas. Esto es más evidente en el caso de Lavanha, porque todas sus funciones, incluyendo la de autor, dependían de los nobles a los que servía. Los escasos datos biográficos sobre Brito me impiden saber si la publicación de sus dos tomos le valió algún beneficio inmediato. Por eso conviene cerrar esta parte con las observaciones de Anne Cayuela respecto de la producción literaria en la época en que se escribe y publica este Naufragio:

[...] les relations économiques conditionnent pour une grande part la production artistique. Le fait que l'écrivain ne puisse pas vivre de sa plume et soit à la recherche ou au service d'un noble détermine un système de production littéraire dont le texte des marques explicites (comme le nom du noble sur le frontispice, les dédicaces qui lui sont adressées [...]. On peut donc suggérer que les formes de dépendances existantes exerçaient une influence sur la littérature dans la mesure où la production de certains auteurs était conditionnée par des impératifs d'ordre financier (1996: 67).

La primera parte de la dedicatoria está abreviada en la portada de la relación, la segunda y la tercera se encuentran en el cuerpo del texto de la dedicatoria cuyo encabezado es "Ao Príncipe N. Senhor". Ya he analizado las dos más obvias, pero la tercera se desliza de modo menos evidente. Aquí Lavanha cambia de tono y es un tanto contradictorio su discurso en relación con el principio en donde ya se vio que no pretende escribir en tono trágico. No obstante, aquí hace referencia a las penalidades que pasan los portugueses en la llamada "Carreira da Índia":

Se nela puser V. A. os olhos (grande premio de tão pequeno presente) verá os perigosos trabalhos, que sofrem estes seus vassalos na larga navegação da Índia. Onde pelejando continuamente com infiéis, arriscam \& perdem as vidas: \& quando com muito sangue derramado ficam com elas, \& as vêm gozar à sua pátria, com o merecido fruto das suas vitórias, alcança as deles o mar, enojado da ousadia com que o passeiam, \& furioso perde as suas naus, \& dá com elas à costa, como fez a esta.

Una vez visitado el recurso de la humilitas con el que Lavanha extiende sus reverencias, parece contradecirse en relación con el inicio de su epístola dedicatoria. Al principio anunció el descubrimiento de una tierra y un camino, y dijo que tuvieron 
"comodidades inesperadas"; ahora se refiere a los sufrimientos que padecen los vasallos portugueses del príncipe heredero en los largos viajes a la India, exponiendo la vida no sólo frente a los peligros de la navegación sino también frente a otros hombres. La intención queda más clara con lo que añade a continuación: "Porém a tudo os portugueses contrastão, \& e por tudo passam com animosos e alegres peitos, pela honra de Deus, \& e pelo serviço de S. Majestade, e de Vossa Alteza, Felice, \& firme Império" (mi subrayado). Lavanha pone el acento en el valor de los portugueses que se hacen a la mar. Al señalar el arrojo de la colectividad de la cual él procede y a la cual pertenece la mayor parte de sus receptores, Lavanha se quiere ganar también la voluntad de su público, por eso concluye su exordio con una construcción elogiosa que provoca en el receptor su atención y benevolencia, tal cual lo recomienda la retórica (Herenio, 2010: I, 7 y 8). Del príncipe necesitaba favores tangibles y de los lectores esperaba atención.

\section{Aviso de náufragos}

Como otros títulos de la época, el de Lavanha es descriptivo. Además de Naufrágio, el título añade \& itinerario da gente que dele se salvou. Lavanha no incluye términos que aludan a penalidad alguna. Esto contrasta con numerosos ejemplos de la antología y de la época: en la primera edición del naufragio de Sepúlveda, el título es História da muy notavel perda do Galeão grande Sam João. Em que se contam os innumeraveis trabalhos e grandes desauenturas que aconteceram ao Capitão Manuel de Sousa de Sepulueda. E o lamentauel fim q elle \& sua moler \& filhos \& toda mais gente ouuerão (Boxer 1957: 6-7). En el caso del naufragio de la nao São Bento el título avisa que el texto contiene Naufragio, Summario e seus trabalhos e morte. Una de la ediciones del naufragio de la nao Conceição se titula Relaçam do lastimozo naufragio da nao Conceiçam ... (Boxer, 1957: 12). Charles R. Boxer da noticia de que la Biblioteca Nacional de Portugal posee un manuscrito de Gaspar Ferreira Reimão cuyo largo título comienza así: Trattado dos grandes trabalhos que passarão os portuguesses que se salvarão do espantoso naufragio que fez a nnaão [sic] São Thomé... (1979: 103). ${ }^{13}$ Como se ve en el contraste con estos títulos y retirando la parte de la dedicatoria, el de Lavanha, además de evadir las referencias a infortunios, destaca por su brevedad. El título reza naufragio e itinerario. Mientras la primera palabra se vincula sin duda con narración, la segunda es más ambigua, pues se puede entender que se trata del reporte del viaje, pero también "caminho a seguir" (Houaiss, 2001: s. v. itinerário), es decir, una palabra que remite al sentido de guía o manual. Las dos definiciones de Autoridades (1734) igualmente señalan que un itinerario tiene una función y una

\footnotetext{
${ }^{13}$ Mis pesquisas en los catálogos de la Biblioteca Nacional de Portugal arrojan que hay seis registros bajo el nombre de Gaspar Ferreira Reimão, pero sólo uno de ellos es un manuscrito que se titula Roteiro da carreira da India co [m] seus caminhos e derrotas signais e auguages e diferenças dâgulha. Se trata de un conjunto de trece manuscritos, o un manuscrito en trece partes, pero ahí no figura el que señala Boxer.
} 
utilidad. En la primera acepción dice: "La fórmula que se da para dirigir algún viaje"; en la segunda: "Vale también el despacho que se da a los soldados, en que se le señalan los tránsitos para que se les dé en ellos lo que manda la Real Ordenanza". En resumen, la palabra designa el carácter informativo de la relación, lo cual se confirma en el párrafo prologal con el que inicia propiamente el texto. Esto explicaría también la fría prosa de Lavanha si se compara con otros casos. Aunque cabe también la posibilidad de que el famoso y respetado cosmógrafo no tuviera una pluma tan seductora como sin duda era su labia.

Que los títulos repercuten en el modo de su recepción no hay duda. Los primeros lectores de los textos eran los censores. Por eso, las licencias de ambas ediciones son de interés. En la edición de 1597 hay tres licencias que caben en una sola cara del folio. Dos son meras fórmulas de veras sucintas que podrían aparecer en cualquier libro de la época, no añaden ningún comentario; pero fray Manoel Coelho, cuya licencia es la primera, después de señalar la fórmula referente a que no encuentra nada contra la fe y costumbres, se permite una breve opinión cuyo inicio es también formulístico pero iluminador: "antes me parece obra necessária \& que servirá de aviso em muitas coisas aos que navegam às partes da Índia, por onde me parece que se pode imprimir". No hay alusión a sufrimientos, penalidades y tragedias, sino énfasis en su carácter de aviso, es decir, es advertencia, prevención, recomendación de los cuidados que deben tener los navegantes.

Las licencias de la antología de Brito, como bien ha señalado Antonio Tabucchi (1988), tienen la impronta del título que el editor le dio a su compilación. Todas ellas son bastante amplias, como si su extensión estuviera en concordancia con una obra en dos tomos. Algunas las firman personajes importantes en la "cultura ufficiale dell'epoca", según información de Tabucchi $(28,32)$. Pero las licencias y aprobaciones de cada tomo confirman la observación que he hecho antes en el sentido de que cada tomo es distinto. Por un lado, Fray Manoel de Sá, dice que el tomo I "no teatro da História, representa um papel verdadeiramente trágico". El censor Julio Francisco consigna que el libro será "utilíssimo para que os que houverem de navegar, desenganados dos muitos e gravíssimos perigos de vida a que se expõem, concebaõ hum santo temor da morte". En otras palabras, su recepción del tomo tiene como punto de referencia el escarmiento. Por otro lado, ya en el tomo II, la aprobación del académico fray Francisco Xavier de Santa Teresa en un breve ensayo crítico donde afirma que los naufragios de la compilación de Brito "excedem no horror dos sucessos a todas aquelas tão memoráveis tempestades, que descrevem Virgílio [...], Ovídio [...], Estácio [...], Silio Itálico [...] Valerio Flacco [...] Juvenal [...] e Gadio". ${ }^{14}$ Es innegable el efecto del texto de Lavanha en el párrafo final de esta aprobación. Aunque el autor no deja de aludir al "lastimoso naufragio" de la nao Santo Alberto, entiende el tomo II como guía: "este livro depois de impresso servirá sem dúvida de melhor roteiro a todos os navegantes

\footnotetext{
${ }^{14}$ Reduje el texto, que informa de los pasajes específios de las obras donde hay naufragios.
} 
dos mares da Índia, como já observou o mais sábio cosmógrafo de Hespanha Joaõ Baptista Lavanha". A pesar de esta observación, en el tomo II hay naufragios que no tienen ese sentido didáctico, pero la idea que expresa el autor de la aprobación proviene de la lectura atenta de la relación de Lavanha. Sin embargo, estas observaciones son únicamente del conocimiento del lector especializado, pues ninguno de estos textos forma parte de las ediciones modernas de la História trágico-maritima.

El prólogo da noticia explícita sobre la intención, objetivo o finalidad de lo escrito, además de otra información que no es la obra. Por ejemplo, el prólogo del naufragio de Sepúlveda —que según Boxer (1957: 9) aparece desde la primera edición conocida de 1564 - expresa que la finalidad del texto es "para os homens muito temerem os castigos do Senhor e serem bons cristãos" (Brito, 1956: I: 13), palabras que dejan ver reminiscencias de los relatos medievales ejemplares. En la relación de João Baptista Lavanha, el primer párrafo expresa cuál es el objetivo, declara el género de texto que escribe ("este breve tratado") y avisa cuáles fueron sus fuentes. Al igual que el autor del naufragio de Sepúlveda, Lavanha busca que su relación sea ejemplar, pero no desde el ángulo moralizante de aquél sino de una manera práctica, para que sea "menor a perda no mar \& mais segura a peregrinação por terra" (2). Afirma que la noticia de la perdición de la nao Santo Alberto y la relación del camino "são de grande importancia para nossas navegações \& para aviso delas muy necessárias. Porque o naufrágio ensina, como se devem haver os navegantes em outro que lhes pode acontecer" (1). Ésta es la confirmación de la intención autoral que ya se había declarado antes.

Se debe a la finalidad práctica del texto la contención con que se narran las desventuras de los sobrevivientes del naufragio. Lavanha no puede permitirse ahondar en la construcción de las emociones o temores de los náufragos porque su aspiración es que su texto ofrezca conductas modélicas que no podría lograr con descripciones dramáticas, pues provocaría temor cuando su intención era infundir valor y orientar hacia un comportamiento racional. De hecho, en esta narración los infortunios se esbozan, porque Lavanha sólo reporta, no pinta: "tornando ao caminho, \& subindo outro monte, esperando descobrir dele povoado, não viram senão estendidos, \& desabitados campos, que os desconsolou, \& entristeceu. Alojaram aquela noite, onde havia comodidade de lenha \& água" (58).

En otras relaciones los narradores aprovechan tormentas u oleajes, fallas en alguna parte de la maquinaria del barco, o las penalidades de la peregrinación por tierra para mover los ánimos del receptor mediante descripciones que pinten el terror, el desastre o el peligro; pero Lavanha construye un relato en el que los pasajes más proclives al dramatismo son escasos y referidos con precisión, pero evitando al máximo la amplificación o la profundización en detalles. La nao Santo Alberto naufragó porque iba sobrecargada, le entró agua y todas las composturas que hicieron fueron inútiles, así que se fue partiendo. El pasaje que cito a continuación es el que describe con mayor intensidad el momento del naufragio, corresponde a la pérdida definitiva de la embarcación: "Caíram os mastros, com grande e lastimosa grita de toda a gente. Caídos os mastros, deitaram-se muitos a eles inconsideradamente, parecendo-lhes seguro remédio 
para escapar do naufrágio. Mas como estivessem ainda pegados com alguma enxárcia, as impetuosas ondas que com grande fúria rebentavam na nau, deram neles e todos afogaram, com pernas e braços quebrados" (11).

Después del episodio anterior, es evidente que el narrador procura no incurrir en detalles que refieran malestar, inquietud o desesperación, a pesar de que a lo largo del texto se deslicen situaciones de gran fuerza emotiva, entre las cuales la más recurrente es el abandono de personas que no resisten las duras jornadas a pie. En este sentido, en la narración se pone de manifiesto la jerarquía social, pues Lavanha sólo menciona estos casos de manera rápida cuando se trata de subalternos: "Deste vale (onde ficaram quatro escravos, dois cafres, um japão, $\&$ um jau ${ }^{15}$ ) à que os nossos puseram nome da Misericórdia...” (86). En cambio, se extiende - pero no demasiado - cuando el personaje es portugués, como en el siguiente fragmento, que es, de hecho, el más dramático una vez que están en tierra y quizá el más conmovedor de toda la relación:

[...] ficou um velho de lxxv anos, por nome Álvaro Gonçalves, pai do contramestre, que vinha mui doente, $\&$ todos os companheiros tão cansados que o não podiam mais levar aos ombros, como até li fizeram. Quisera o piedoso filho ficar com ele, \& não se permitindo, deixou-lhe cobre, pera comprar o que houvesse mister, \& em um papel escrito os nomes das cousas necessárias, pera as pedir aos negros \& com gerais lágrimas de tão lastimoso apartamento o tiraram junto do seu pai, que com uma bênção o despediu, ficando confessado, \& como bom cristão mui conforme com a vontade de Deus (120-121).

Mientras en otras relaciones los pasajes como el anterior abundan y son proclives a la amplificatio, en la de Lavanha son meros esfuerzos por darle color al texto.

Desde el inicio, después de haber narrado cómo se destroza la embarcación, Lavanha hace un paréntesis considerable para enumerar los motivos por los cuales se han perdido muchas naves portuguesas que van camino de la India, lo cual interrumpe la emoción del naufragio y reorienta la atención hacia el ángulo explicativo del texto. La mayor parte de lo que narra o describe se relaciona con el propósito de servir de ejemplo sobre cómo actuar o qué esperar durante el recorrido. Las descripciones de los espacios en general no infunden temor sino que ilustran las "comodidades" que le anuncia en la dedicatoria al príncipe. Por eso más de una vez parece evocar locus amoenus: "aos xv de Abril, quinta-feira santa, se começou caminhar antes que saisse o sol, por boa terra, de fermosos campos e abundosos pastos, \& atravessaram duas ribeiras, em uma das quaes se detiveram uma hora" (55). Varias veces los negros los reciben con bailes para celebrar a los "hijos del Sol" (118) pues los sorprende el color de su piel, sorpresa que se extiende a los propios animales, por eso hay pasajes tan curiosos como éste (mi subrayado): "Os quais [cafres] se estranhavam os nossos pela diferença da cor, \& dos trajos, não menos se estranhavam as suas vacas, porque

${ }^{15}$ Javanés. 
correndo de longe aos portugueses, paravam junto deles, com os focinhos no ar, como maravilhadas de coisa tão nova" (49). Es de suponer que entre los navegantes no sólo existía el temor al naufragio en sí, sino también a los animales que podrían encontrar en el camino una vez en tierra. Esto puede explicar la insistencia en referir el carácter amigable de las vacas y la aclaración explícita de que en la zona en la que se perdieron hay "grandes e espessos bosques nos quais nunca se encontraram leões, tigres nem animais desta qualidade" (30). El temor a las grandes fieras puede encontrar su origen en la relación del naufragio de Sepúlveda, en cuyo final se sugiere que al capitán, tras internarse falto de razón en esos "bosques", lo pudieron haber comido tigres o leones. Este detalle funcionaba muy bien en esa relación que pretendía a toda costa conmover al receptor, pero era contraproducente para un texto con objetivo distinto. Asimismo, el hecho de que estos náufragos hubieran recorrido lugares cercanos a los de Manuel de Sousa Sepúlveda hacía necesaria la aclaración (146).

Además de los pasajes explicativos, hay otros con recomendaciones explícitas para los sobrevivientes, lo que pone aún más de manifiesto el carácter de aviso de la relación. Lavanha advierte sobre aquello que se debe conservar tras el naufragio con la finalidad de intercambiarlo por víveres, ganarse la voluntad de principales que se vayan encontrando a su paso, tener presentes orientaciones geográficas o recomendaciones de rutas. Ilustro con el siguiente ejemplo y destaco la parte más evidente con cursivas: "São estes negros mais cobiçosos \& interesseiros que os de atrás, \& por cobre [...] porque davam os outros três vacas, deram uma, não tendo já tanta valia entre eles como entre os passados \& estimando-se a roupa, que os outros não queriam. Pelo que convêm fazer grande cabedal de cobre \& ferro para o resgate dos mantimentos té esta paragem $\&$ guardar os panos, para o fazerem daqui por diante" (105).

Lavanha concluye su relación enfatizando que el viaje no estuvo lleno de penalidades, pues afirma que los sobrevivientes, cuando por fin encontraron a los portugueses que los llevarían a Portugal, fueron con los frailes dominicos a dar gracias "pelos extraordinários benefícios, \& singulares mercês recebidas de suas divinas \& liberais mãos" (152). No obstante, es difícil creer que tres meses de camino sin conocimiento del lugar hayan sido como los describe Lavanha. Leyendo entre líneas, hay evidencias de que el narrador incurrió en importantes silencios. Anteriormente aludí a la escasez de pasajes dramáticos, pero también es posible detectar que, a pesar de que el texto invoca a los beneficios de la unidad y hace una exaltación de la figura del capitán Nuno Velho Pereira, había discrepancias, roces, pillajes e intentos de motín. El ejemplo más revelador en este sentido lo ofrece el autor cuando menciona que un grupo de sobrevivientes se separó del grupo que conducía Nuno Velho Pereira: "ficou o tempo levante donde estava, \& assim foi necessário esperar à outra Lua seguinte. De que enfadados alguns portugueses, \& assim da estreiteza do navio, \& carestia de água, determinaram de ir por terra até Sofala" (151). Pero sólo hace esto para explicar que de todos ellos (sin precisar el número de disidentes), únicamente dos sobrevivieron. Es decir, incluye esta información para infundir temor porque pretende enseñar mediante el ejemplo negativo, con el objetivo de reforzar la continuidad de la estructura 
social en un contexto lejano y proclive a la crisis: no hay que dudar de la habilidad de los capitanes, parece ser la consigna del autor, quien tenía presente en todo momento el naufragio de Sepúlveda, pues lo menciona explícitamente, así que habrá que suponer que esa relación había causado gran impacto y tanto los marineros como los viajeros temían pasar por las mismas penalidades. Si a esto se añaden otros naufragios ocurridos en la zona, es de comprender la actitud del cosmógrafo real. De alguna manera, el texto de Lavanha está dialogando constantemente con la relación del naufragio de Sepúlveda, pero para desdecirla. De ahí que haya tantos pasajes en los que el narrador se refiere a "os nossos", "nossos portugueses" y siempre sea en un contexto en el que el capitán y la compañía aciertan en un comportamiento o se defienden de manera eficaz de los engaños de los aborígenes. Tal parece que el encargo que ejecutó Lavanha hubiera tenido dos objetivos: servir de guía o manual y subirle la moral a los navegantes. En otras palabras, el naufragio de Sepúlveda habría tenido un éxito considerable y había causado impacto en la memoria de la colectividad, pero en términos prácticos tenía sus bemoles porque infundía temor. Este naufragio que relata Lavanha es la contraparte del de Sepúlveda. Si Brito hubiera colocado el de Lavanha inmediatamente después del que narra el naufragio de Sepúlveda, el contraste sería aún más evidente y el objetivo del texto del cosmógrafo se comprendería de inmediato, pero el texto de Lavanha se publicó hasta el cuarto lugar del segundo tomo.

Leída junto con las otras once relaciones, la de Lavanha es bastante menos trágica, para usar el adjetivo de Brito; da la impresión de que su autor no alcanzó las capacidades narrativas de muchos de los otros autores antologados; pero independientemente de esto, lo que nos enseña la comparación de los paratextos de las ediciones de 1597 y 1736 (o la omisión de ellos en las ediciones contemporáneas) es la estrecha relación entre la materialidad de la obra y las condiciones políticas, sociales y culturales de la época de cada edición. Como se puede ver y aunque parezca imposible, hay mucho trabajo por hacer, porque Brito compiló doce relaciones y aquí se ha hablado apenas de una. Es probable que no todos los cotejos y comparaciones tengan resultados tan sorprendentes como en este caso, pero no sería algo raro si arrojaran alguna sorpresa.

\section{Obras citadas}

BOXER, Charles R. 1957. An Introduction to the História Trágico-Marítima, separata de Miscelânea de Estudos em Honra do Prof. Hernâni Cidade. Lisboa: Universidade de Lisboa.

1979. "An Introduction to the História trágico-marítima (1957): some corrections and clarifications". Quaderni Portoghesi, 5. Pp. 99-112.

BRito, Bernardo Gomes de, comp. 1735 y 1736. História Trágico-Marítima em que se escrevem chronologicamente os Naufragios que tiveraõ as Naos de Portugal, depois que se poz em exercicio a Navegaçaõ da India. Tomo segundo. Offerecido À Augusta Magestade do Muito Alto e Muito Poderosos Rey 
D. Joaõ V. Nosso Senhor. Lisboa Occidental. Na Officina da Congregaçaõ do Oratorio. Com todas as licenças necessárias. 1956 y 1957. História trágico-marítima. Ed. António SÉrGio. Lisboa: Sul. 3 tt.

CAYUela, Anne. 1996. Le paretexte au Siècle d'Or: Prose romanesque, livres et lecteurs en Espagne au XVIIe siècle. Ginebra: Droz.

Diccionario de autoridades. 1734. Real Academia Española. 2 de enero de 2016. $<\mathrm{http}: / /$ web.frl.es/DA.html $>$.

GARÇão, Pedro António Correia de. 1778. Obras poéticas. Lisboa: Regia Officina Typografica. 3 de enero de 2016. <http://purl.pt/243>.

GenetTe, Gérard, 1987, Umbrales. Trad. Susan Lage. México: Siglo XXI.

GüEL, Mònica. 2009. "Paratextos de algunos libros de poesía del Siglo de Oro". Paratextos en la literatura española (siglos XV-XVIII). Ed. María Soledad Arredondo, Pierre Civil y Michel Moner. Madrid: Casa de Velázquez. Pp. 19-35.

HouaIss, Antônio. 2001. Dicionário Houaiss da Lingua Portuguesa. Río de Janeiro: Instituto Antônio Houaiss.

Lanciani, Giulia.1997. Sucessos e naufragios das naus portuguesas. Lisboa: Caminho.

LaVANHA, João Baptista. 1597. Navfragio da nao S. Alberto, e itinerario da gente que delle se salvov. De Ioão Baptista Lavanha Cosmographo mòr de Sua Magestade. Dedicado ao Principe Dom Philippe Nosso Senhor. Lisboa: Alexandre Siqueira.

1895. Itinerario del reino de Aragón. Zaragoza: Diputación Provincial.

MAILlARD, Jean-François. 2003. "Le rôle de la dédicace et de la page de titre dans la naissance de la critique philologique". Offrir un livre ou La dédicace à l'époque humaniste. Bruselas: Musée de la Maison d'Érasme à Anderlecht. Pp. 25-39.

O'ConNoR, J. J. y E. F. RoBERTSOn, “João Baptista Lavanha”. Biographies. School of Mathematics and Statistics / University of St. Andrews, 2014. 2 de enero de 2016. $<$ http://www-groups.dcs.st-and.ac.uk/ history/Biographies/Lavanha.html $>$.

Retórica a Herenio. 2010. Trad. Bulmaro ReYes CORIA. México: UNAM.

SARAIVA, José Hermano. 1998. História concisa de Portugal. Mira-Sintra-Mem Martins: Europa-América.

TABUCCHI, Antonio. 1998. "Interpretazioni della História trágico-marítima nelle licenze per il suo imprimatur”. Quaderni Portoghesi 5. Pp. 19-43.

VERNEY, Luís António. 1950. “Carta VII". Verdadeiro método de estudar. II. Lisboa: Sá da Costa. Pp. 199-337.

VOINIER, Sarah. 2009. "Dedicatoria y poder en unas crónicas históricas del siglo XVII". Paratextos en la literatura española (siglos XV-XVIII). Ed. María Soledad Arredondo, Pierre Civil y Michel Moner. Madrid: Casa de Velázquez. Pp. 283-292. 